\title{
A System for Land Development Approval Management using Geographic Information Systems - A Case Study of Thimbirigasyaya Ward, Colombo
}

\author{
H. H. Leelananda, N. T. S. Wijesekera, T. A. Peiris,
}

Abstract : In a developing Country like Sri Lanka, it is very important to plan and manage its land development programmes to attract investments to develop land resources. In this context special emphasis should be given to urban areas.

The prevailing systems of issuing preliminary land development clearance by the Urban Development Authority (UDA) which is based on a manual filing system consumes significant time and is unable to provide alternative solutions to prospective developers. Most of the countries use Geographic Information Systems (GIS) for similar land management work.

Astudy was carried out, selecting Thimbirigasyaya ward of Colombo Municipal Council (CMC) to develop a GIS based land data management system in order to carry out the management of the land clearances in an efficient manner.

Land parcel information obtained from CMC and UDA were scanned, spatial data were georeferenced and a mosaic was constructed. Input data were subjected to accuracy checks and were verified. Accuracies of data duplication, length, extent etc., were found satisfactory and adequate for UDA land clearance work. The database also incorporates the UDA conditions stipulated for location, zone and regulations enabling the checking of applications. The developed land information system was designed to include all functional aspects in the previous systems and additional capability to provide alternative solutions. The system developed using GIS was verified for computational accuracy using manual calculations. Adequacy checks were done with respect to the approved regulations.

The developed Land Management Information system reduces the application processing time from 40 days to 5 days enabling quick decision-making. Present day IT tools such as Geographic Information Systems enable easy management of land parcels and possesses capability to overlay and analyze special data with minimum time. The present study highlights the data and accuracy requirements of the methodology to develop spatial databases for land development management. It also provides alternative solutions and can be used for land management policy analysis

\section{Introduction}

Sri Lanka is a developing nation in South Asia (Northern Latitude $5^{\circ} 55^{\prime}$ and $9^{\circ} 50^{\prime}$ and Eastern Longitudes $79^{\circ} 42^{\prime}$ and $81^{\circ} 52^{\prime}$.) striving for economic development. Attracting investments and development of its land resource is very important for Sri Lanka. As such, it is important that the national development activities receive the clearances as early as possible. In this context special emphasis for land development in urban area should be given as most of the investments are attracted to urban areas. Granting of necessary clearances in urban area falls under the purview of Urban Development Authority (UDA), which is in the Ministry of Urban
Development \& Water Supply. The UDA grants a "Preliminary Planning Clearance" (PPC) to lands under its jurisdiction so that a developer could then obtain the local government approval for the implementation of final plans (Government Notifications 1999).
H. H. Leelananda B. SC. (EMV) Mgt. (Special)(SJ), PG Dip (Computer Technology)(Col), M. Sc. (CIS) (Moratuwa). Graducted in 1997, Presently Town Plạner, Urban Development Authority.

Eng. (Prof) N. T. S. Wijeselera B. Sc. Eng. Hons (Sri Lanka), PG Dip (Moratuwa), M. Eng. (Tokyo), Ph. D. (Tohyo), MICE(UK), FIE(SL), Graduated in 1979, Presently Professor Civil Engineering. University of Moratuwa, Charted Civil Engineer, Chairman ICGAT.

Eng. (Dr) T. A. Peiris B. Sc. Eng. (Moratuwa), M. Sc. (Lond), DIC, D. Eng (Tokyo). Graduated in 1985, Presently Senior Lecturer, University of Moratuwa. 
A study of the prevailing approval system of the UDA (Figure 1) identified that the process a developer has to undergo to obtain the PPC takes an approximate duration of 45 days(Table 3). It also revealed that the present system requires an application to change hands at least 26 times. This has been indicated as the number of activities to be carried out in the process as shown in the Table 3. At the end of this application processing period if the PPC is not granted then a developer needs to identify an alternative site and resubmit an application for a fresh approval. Even if a person were ready for investment that person would not be able to seek support of the UDA, if he/she has not identified a land. The present system at UDA to grant approval is based on a mechanism where data is acquired, verified and submitted for approval through a manual filing system which consumes a significant handling time and significant field inspection \& verifications time.

Geographic Information Systems are widely used in most countries for similar land clearances (Chandrasekhar 2003, Iftikhar and Franklyn 2002, Lee and Tan 2002, Peter and John 1988, Potdar
2003). Such systems are known to consume less time and also reliable with respect to data acquisition, storage, retrieval and analysis. Therefore if a GIS could be developed for the UDA's PPC activity then it will contribute immensely towards the National Development activities in urban areas. A GIS of this nature needs to have basic information such as Average household income, Population density, Land use, Land value, Land ownership, and basic land parcel data among others (United Nation 1995). In the present work, a GIS has been developed for land development approval and the management of such approvals at the UDA. The GIS has been verified for data accuracy, computational accuracy and the ability to provide requisite outputs for decision-making. It is noted that the scientific development of a reliable land clearance system could immensely support the engineers and others in land development activities. The selected location for the study is the Thimbirigasyaya Ward of the Colombo Urban Area. Colombo is the commercial capital of Sri Lanka, which is located in the west of the island (Figure 2).

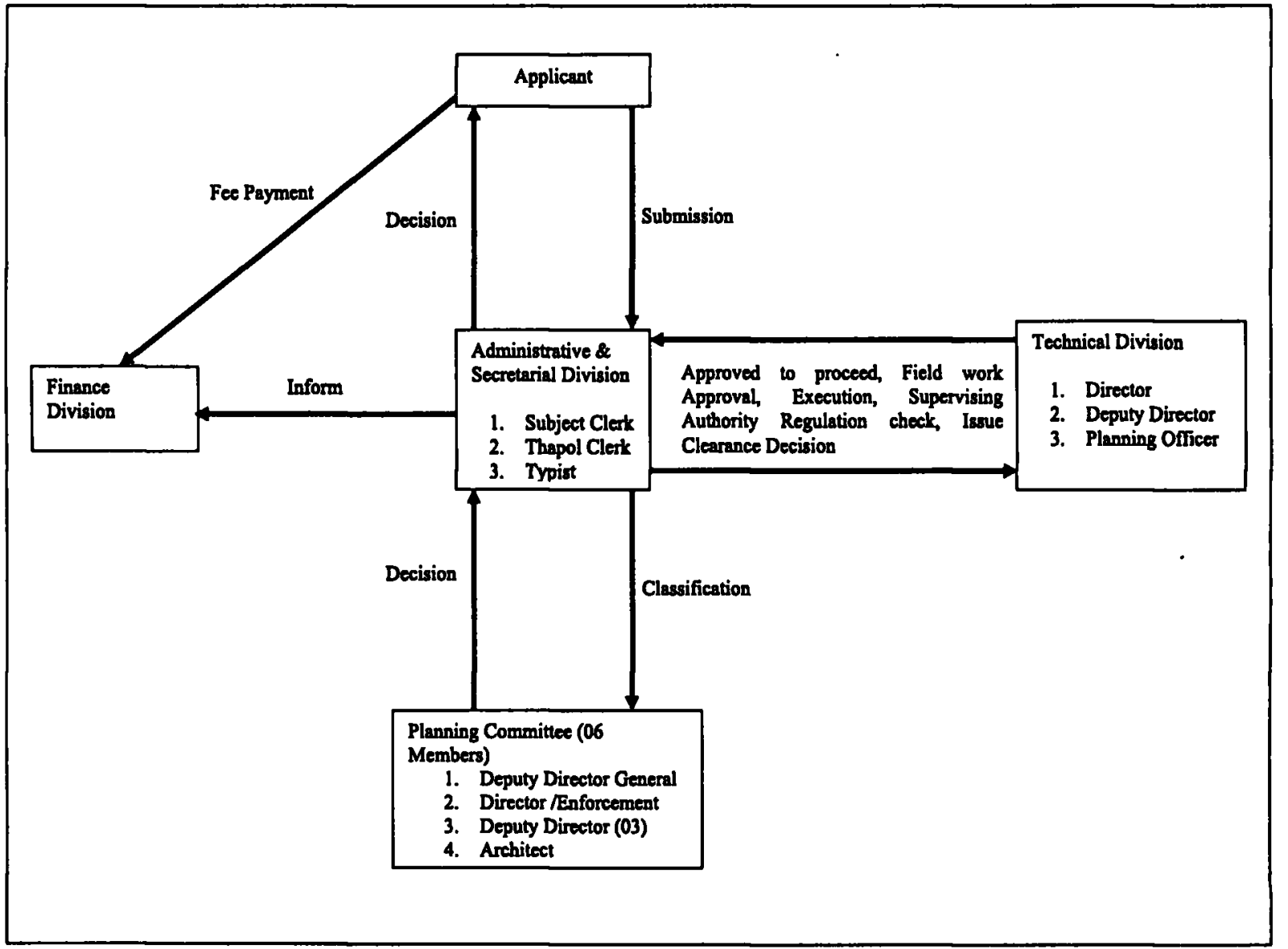

Figure 1 : Present Contributing System for Approval and the officials involved in PPC 


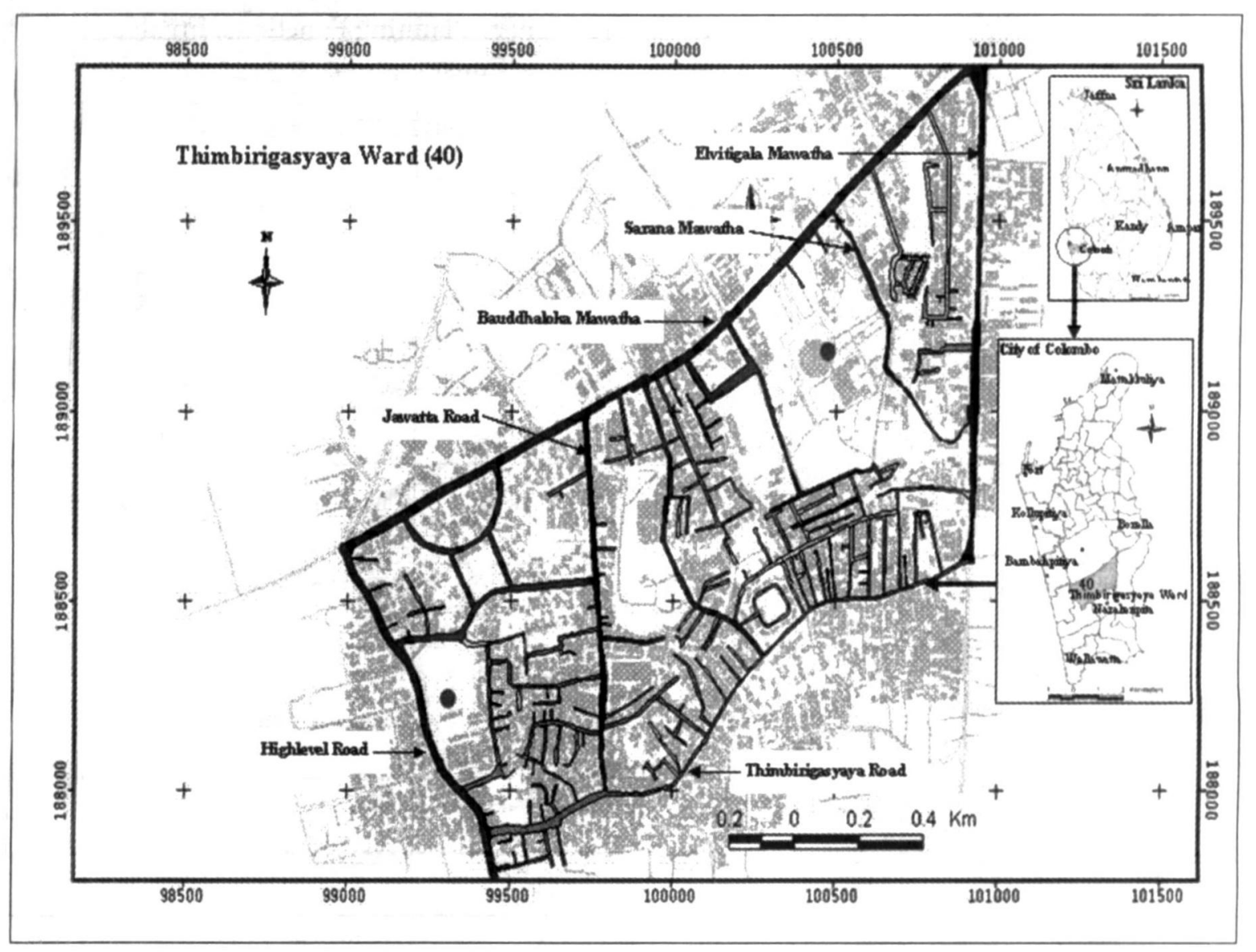

Figure 2 : Location of Study Area

\section{Site Selection and Data}

The Colombo Municipal Council (CMC) covers an extent of 3729 ha and has a population density of 188 persons/ha. There are 47 wards in the $\mathrm{CMC}$. The wards of CMC were compared with each other considering the updated data availability and the available opportunities for development. Out of the data available on locations, it was identified that the Thimbirigasyaya ward (Figure 2), which has an area of 162 ha and 1404 land parcels had the maximum density of vacant lots, the minimum plot coverage, minimum floor area ratio, minimum density of slums \& shanty and minimum population density. The comparison of these parameters indicated that the Thimbirigasyaya ward had the maximum development potential and as a result an important area in terms of land development. The procedure for selection including the maps of base data, classification criteria, and the flowchart of selection is given in Figure $3 a, 3 b, \& 3 c$. Therefore Thimbirigasyaya was selected for the land information system development and complete details of selection computatios are in Leelananda
(2005). The data of Thimbirigasyaya ward in the Colombo Municipal Council (CMC) used for the study are shown in Table 1.

The Land Parcel information available at the assessment department of the $\mathrm{CMC}$ were scanned and taken for database preparation. These spatial data were georeferenced and a mosaic was constructed using 24 images, which were scanned in TIFF image format. Screen digitizing and attribute data table entries were done to develop the GIS. Field inspections were carried out to check map and attribute data.

The accuracy of the digital database was checked for errors during photocopying and scanning. These errors in the values used for the database were found very low (Table 2) considering the needs of the Urban Development Authority and also giving due consideration to the high land prices in the study area. Also since the UDA regulations published in the reference cited as UDA (1999) concerning the approvals also had classifications changing at intervals of 1 square meter per hectare, the data input accuracies which were much higher could be considered adequate for UDA land clearance work. Duplication 
Table 1 : UDA Manual Clearance Systems - Preliminary Planning Functions, Involved Personnel and Approximate Time Consumption

\begin{tabular}{|c|c|c|c|c|c|c|c|}
\hline \multirow[b]{2}{*}{ 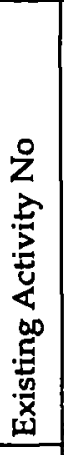 } & \multirow[b]{2}{*}{ 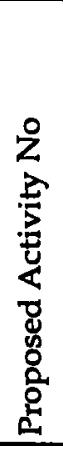 } & \multirow[b]{2}{*}{ 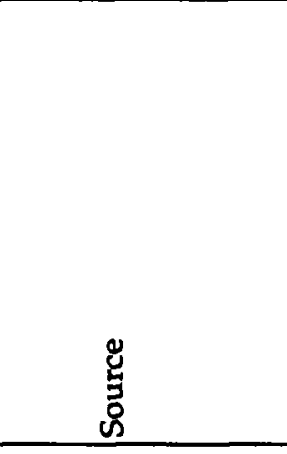 } & \multirow[b]{2}{*}{ 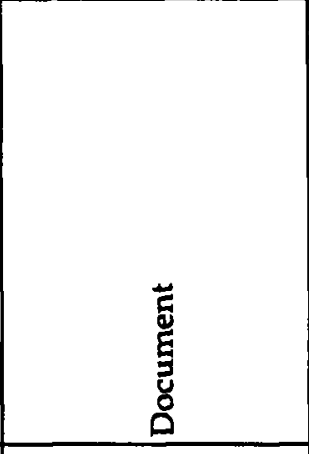 } & \multirow[b]{2}{*}{ 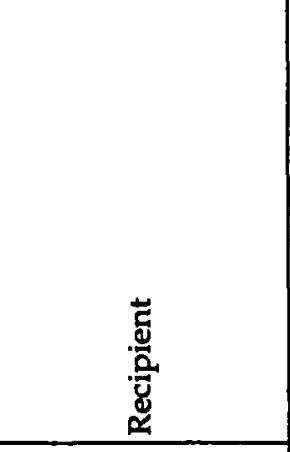 } & \multirow[b]{2}{*}{ 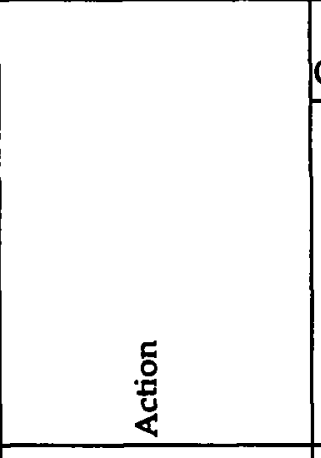 } & \multicolumn{2}{|c|}{$\begin{array}{c}\text { Time } \\
\text { Consumption }\end{array}$} \\
\hline & & & & & & 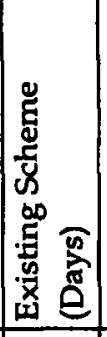 & 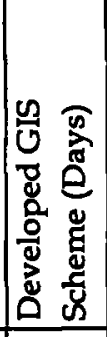 \\
\hline 1 & 1 & Applicant & $\begin{array}{l}\text { Clearance } \\
\text { Application }\end{array}$ & Subject Clerk & $\begin{array}{l}\text { Payment and } \\
\text { registration }\end{array}$ & \multirow[t]{2}{*}{0.5} & \multirow[t]{2}{*}{0.5} \\
\hline 2 & 2 & Subject Clerk & Payment Voucher & Applicant & $\begin{array}{l}\text { Pay to finance } \\
\text { division } \\
\end{array}$ & & \\
\hline 3 & 3 & Applicant & Paid & Finance Division & Pay to Cashier & 0.5 & 0.5 \\
\hline 4 & 4 & Finance Division & $\begin{array}{l}\text { Copy of Voucher } \\
\text { Form }\end{array}$ & Subject Clerk & Mark Payment & \multirow[t]{2}{*}{01} & \multirow[t]{3}{*}{01} \\
\hline 5 & 5 & Subject Clerk & File with Application & Director & $\begin{array}{l}\text { File to Deputy } \\
\text { Director }\end{array}$ & & \\
\hline 6 & 6 & Director & File & Subject Clerk & Mark File Movement & \multirow[t]{2}{*}{01} & \\
\hline 7 & - & Subject Clerk & File & Deputy Director & File to Deputy Director & & 0 \\
\hline 8 & - & Deputy Director & File & Subject Clerk & Mark File Movement & \multirow[t]{2}{*}{01} & 0 \\
\hline 9 & - & Subject Clerk & File & Planning Officer & To Planning Officer & & 0 \\
\hline 10 & - & Planning Officer & Required Documents & Subject Clerk & Inform to the Applicant & 05 & 0 \\
\hline 11 & - & Planning Officer & File with Field Report & Deputy Director & Check Field report & 03 & 0 \\
\hline 12 & - & Deputy Director & File & Subject Clerk & Planning Committee & 01 & 0 \\
\hline 13 & $\cdot$ & Subject Clerk & File & Planning Committee & Mark File Movement & 01 & 0 \\
\hline 14 & - & Planning Committee & File & Subject Clerk & Committee Decision & 05 & 0 \\
\hline 15 & - & Subject Clerk & File with Decision & Director & Letter preparation & 01 & 0 \\
\hline 16 & - & Director & File & Subject Clerk & Letter Preparation & 02 & 0 \\
\hline 17 & - & Subject Clerk & File with Draft Letter & Typist & Letter Typing & 01 & 0 \\
\hline 18 & - & Typist & File & Subject Clerk & Draft Letter & 02 & 0 \\
\hline 19 & - & Subject Clerk & File with Draft Print & Planning Officer & Letter Correction & 01 & 0 \\
\hline 20 & - & Planning Officer & File & Subject Clerk & Draft Letter & 02 & 0 \\
\hline 21 & - & Subject Clerk & File & Typist & Typing Mistakes & 01 & 0 \\
\hline 22 & - & Typist & File with Final Print & Subject Clerk & Mark File Movement & 02 & 0 \\
\hline 23 & 7 & Subject Clerk & File with Final Letter & Director & For Signature & 01 & 01 \\
\hline 24 & 8 & Director & File with Singed Letter & Subject Clerk & Mark Movement & 02 & 02 \\
\hline 25 & - & Subject Clerk & Signed Letter & Tappol Clerk & To Post & 01 & 0 \\
\hline 26 & - & Tappol Clerk & Letter & Applicant & Received Letter & 05 & 0 \\
\hline \multicolumn{6}{|c|}{ Total Time Period for issuing Preliminary Planning Clearance } & 40 & 5 \\
\hline
\end{tabular}




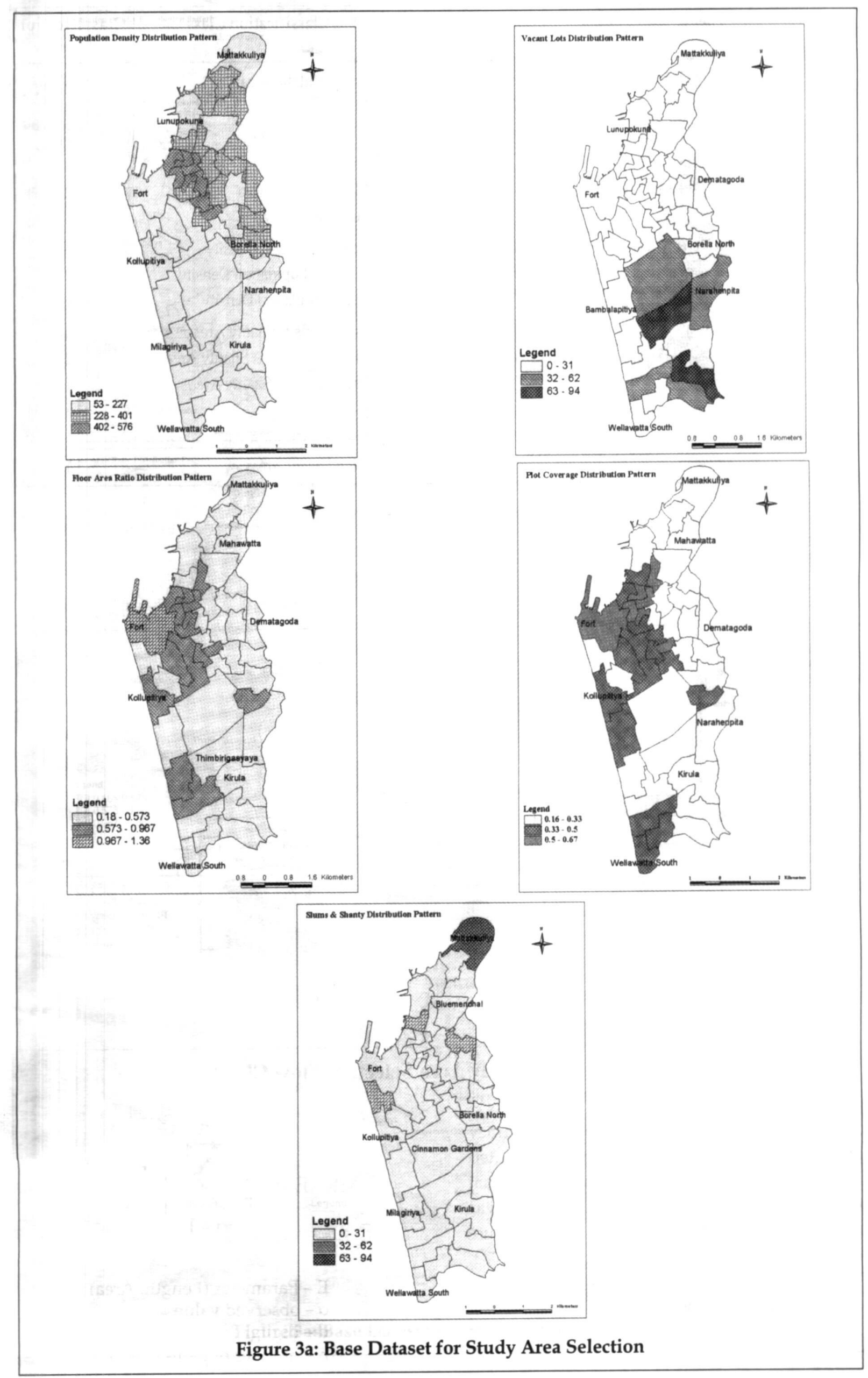




\begin{tabular}{|c|c|c|c|c|}
\hline No & Theme & Computation & Classification Class & $\begin{array}{l}\text { Classification } \\
\text { Range }\end{array}$ \\
\hline 01 & Plot Coverage & $\begin{array}{l}\text { Ground floor area of ward } \\
\text { Extent of Ward }\end{array}$ & $\begin{array}{l}\text { Low buildable area } \\
\text { Medium buildable area } \\
\text { High buildable area }\end{array}$ & $\begin{array}{l}3 \\
2 \\
1\end{array}$ \\
\hline 02 & $\begin{array}{l}\text { Floor Area Ratio } \\
\text { (Building to Plot area ratio }\end{array}$ & $\begin{array}{l}\text { Total Floor Area in Ward } \\
\text { Extent of Ward }\end{array}$ & $\begin{array}{l}\text { Low Floor Area } \\
\text { Medium Floor Area } \\
\text { High Floor Area }\end{array}$ & $\begin{array}{l}3 \\
2 \\
1\end{array}$ \\
\hline 03 & Population Density & $\begin{array}{l}\text { Total Population in ward } \\
\text { Extent of Ward }\end{array}$ & $\begin{array}{l}\text { Low Population Density } \\
\text { Medium Population Density } \\
\text { High Population Density }\end{array}$ & $\begin{array}{l}3 \\
2 \\
1\end{array}$ \\
\hline 04 & Slums \& Shanty & $\begin{array}{l}\text { Slums \& Shanty Area in Ward } \\
\text { Extent of Ward }\end{array}$ & $\begin{array}{l}\text { Low Slums \& Shanty Area } \\
\text { Medium Slums \& Shanty Area } \\
\text { High Slums \& Shanty Area }\end{array}$ & $\begin{array}{l}3 \\
2 \\
1\end{array}$ \\
\hline 05 & Vacant Lands & $\begin{array}{l}\text { Vacant Land area in Ward } \\
\text { Extent of Ward }\end{array}$ & $\begin{array}{l}\text { Low Vacant Areas } \\
\text { Medium Vacant Areas } \\
\text { High Vacant Areas }\end{array}$ & $\begin{array}{l}3 \\
2 \\
1\end{array}$ \\
\hline
\end{tabular}

Figure 3b: Criteria for Study Area Selection

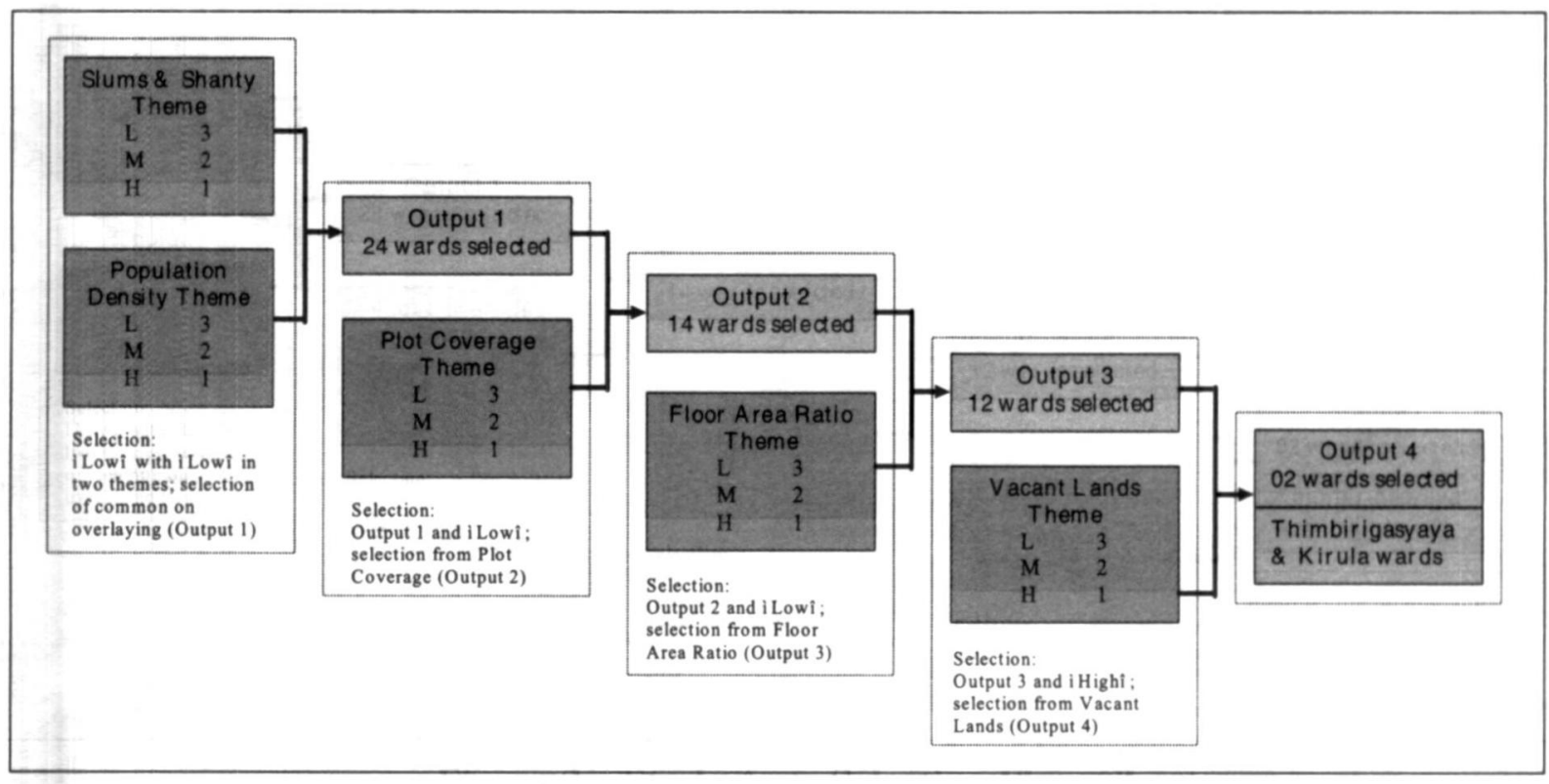

Figure 3c: Study Area Selection Flow Chart

Accuracy, Length Accuracy, and Extent Accuracy of the map data used for the study was computed and compared. In each case comparison of actual values with the values taken to the database was done using the indicator "Mean Ratio of Absolute Error (MRAE)" (Wijesekera \& Abeynayake 2003, Wijesekera \& Chandrasena 2002). The MRAE is taken as shown below.

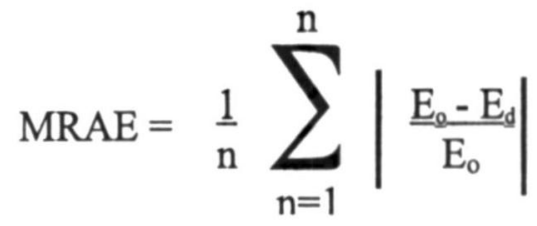

E - Parameter (Length, Area)

o- observed value

$\mathrm{d}$ - digital database value

$\mathrm{n}$ - number of items checked 
Duplication accuracy is the accuracy level of the data when duplicated from originals at the assessor's department of CMC. The duplication accuracy for all 24 maps was computed for checking of data coping. Once the data were registered in the database, the area of the land parcels and the road frontage lengths were also compared with real values. The land parcel area in the database and the original were compared to identify the Extent Accuracy. For this comparison a sample of 110 parcels was selected from eight identified locations distributed in the ward. Road frontages of another selected 70 allotments were measured in the field and were compared with the lengths in the prepared database to identify the length accuracy. Apart from the above, physical checks were performed for the 110 land parcels to compare and verify details such as the approximate geographical position, assessment number, number of floors and access road details. Coordinate checks of geographical locations were done using a hand held Global Positioning System (GPS).

\section{Methodology}

\subsection{GIS Development}

The present Land Clearance System and the officials involved (Figure 1) with the Preliminary Planning Clearance (PPC) were studied in detail. It was identified that the PPCinvolved 11 officials. This study also identified that an application for clearance had to be exchanged 26 times between these officials and consumes an approximate duration of 40 days (Table 1). The present land clearance system requires the coordination of Finance, Administration and Technical Divisions together with the planning committee to enable the assessment of an application. Based on the activities that have to be carried out, a suitable methodology for the structure of digital database was identified and then the process for the Geographic Information System (GIS) was developed accordingly (Figure 4). The proposed database consists of properly developed digital map layers consisting of data such as Assessment Number, Access Road Name, Parcel Extent, Zone Name, Minimum Lot Sizes, Minimum no of Floors, Maximum no of Floors, Usage, Building Heights, Age of Building, Number of Floors, Tenancy Types, Ground Floor Area, Total Floor Area, Road Name, Road Type, Road Width, and Road Length. The Arc View GIS software was used for the spatial database development. The database also consists of the UDA conditions stipulated for location, zone, and regulations enabling the checking of applications as attribute information. This geographic information system would perform checks in a systematic order using a database query system available with the software and identify the comparisons for approval or rejection. The structure proposed for the new information system includes all functional aspects in the previous system. It also has an additional capability to provide alternative solutions in case an investor's original proposal does not satisfy UDA regulations. The Land clearance system uses the multi layer operation capability of GIS to carry out overlaying of land parcels to engineer the land planning and management. The multi layer operations are structured to combine field information, applicant submissions and regulations to give a multitude of options for efficient land planning and management.

Table 2 : Data Used for the Study

\begin{tabular}{|c|c|c|c|c|}
\hline Item & Description & Source & Attribute Data & Scale \\
\hline 01 & Land Parcel Maps & CMC & Assessment Number, Access Road Name, Parcel Extent & $\begin{array}{l}1 \text { Inch: } 1 \\
\text { Chain }\end{array}$ \\
\hline 02 & Zoning Map-2010 & UDA & $\begin{array}{l}\text { Zone Name, Minimum Lot Sizes, Minimum no of Floors, } \\
\text { Maximum no of Floors }\end{array}$ & $1: 1,000$ \\
\hline 03 & Building Maps & UDA & $\begin{array}{l}\text { Assessment Number, Usage, Building Heights, Age of } \\
\text { Building, Number of Floors, Tenancy Types, Ground Floor } \\
\text { Area, Total Floor Area }\end{array}$ & $1: 1,000$ \\
\hline 04 & Road Maps & UDA & Road Name, Road Type, Road Width, Road Length & $1: 1,000$ \\
\hline
\end{tabular}

UDA - Urban Development Authority, CMC-Colombo Municipal Council 
The conditions of UDA were incorporated in the GIS for evaluation of land clearance applications. A given proposal can either be for a residential or non-residential purpose. When the development proposal is a non-residential one, the GIS, first checks the zone. If the proposal is for residential purposes then the system would not go for checking the zone because in all three zones of the study area residential developments are permitted (Table 4). If the development proposal is for non-residential purpose then there are restrictions in the Special Primary Residential Zone and there is no restriction in other zones. Minimum lot sizes are given by the regulations for different zones. The minimum permissible extents in Special Primary Residential, Primary Residential, and Mixed Development zones are 500,250 , and $150 \mathrm{~m} 2$ respectively. Maximum No of Floors given by the regulations for different zones are, 03 floors for Special Primary Residential, 10 floors for both Primary Residential, and Mixed Development Zones. For a proposal for residential purposes, the approved maximum plot coverage is $65 \%$ whereas for a non-residential purpose the approved maximum plot coverage can be increased up to $80 \%$.

\subsection{GIS Accuracy}

The model developed using GIS was verified for computational accuracy using manual calculations and also adequacy checks were done with respect to the approved regulations to ensure that the output through the database is the same as when the work is done manually. Randomly selected ten applications submitted for the UDA approval were tested using the GIS for the fulfillment of the approval/rejection issued by UDA. The checks indicated that the model was satisfactory with respect to both the abovementioned factors. Attribute accuracy of the GIS was checked with manual comparative checks of actual and entered data in the database.

Attribute data accuracy checks consisted of two parts in which the first one ensured that attribute data are properly linked to spatial data. The second is to verify the data entry accuracy of attribute data. This check in the research process was done with randomly selected 110 land parcels which were used for attribute data checks. Attribute data of these 110 polygons were printed and checked manually with plot-wise field data for any possible data errors. Another 70 land allotments were used to check the road frontage length accuracy of spatial data. During this check three parcels were found to have significant errors probably due to an error in the original data and since this was beyond the control of the GIS, they were removed and accuracies were computed using the balance 67 parcels. The checks indicated that the accuracy level of data entry and the spatial links were very high mostly due to careful extraction from the assessment registry, and entering.

The model developed was checked for its correctness with 10 Preliminary Planning Clearance (PPC) applications. These documents were processed both manually and through the GIS and results were compared. Stage-by-stage results were also compared to ensure that the digital GIS followed the checks that were required by regulations. The intermittent and final decisions were the same for both computational methods. The model testing carried out the comparison of the following; 1) Zone of proposed land, 2) Requested Activity, 3) Minimum Lot Size, 4) Maximum No of Floors, and 5) Plot Coverage according to details stipulated in UDA (1999). Table 5 indicates the results of testing and the indication that the same final decision was arrived by both the methods.

\section{Results and Discussion}

\subsection{Structure of GIS}

An assessment of the land clearance through the developed GIS indicated that the process of the land clearance could reduce the required duration to 5 days and this could be achieved by the

Table 3 : Data Input Accuracies

\begin{tabular}{|c|l|l|l|l|}
\hline Item & \multicolumn{1}{|c|}{ Type } & \multicolumn{1}{c|}{ Sample Size } & \multicolumn{2}{c|}{ Mean Ratio of Absolute Error (MRAE) } \\
\hline 01 & Duplication Accuracy & All 24 maps & $4 \times 10^{-7}$ & $0.004 \mathrm{~m} 2 / \mathrm{ha}$ \\
02 & Length Accuracy & 70 road fronts & $15 \times 10^{-4}$ & $1.45 \mathrm{~m} / \mathrm{Km}$ \\
03 & Extent Accuracy & 110 parcels & $45 \times 10^{-6}$ & $0.45 \mathrm{~m} 2 / \mathrm{ha}$ \\
\hline
\end{tabular}


Table 4 : Urban Development Authority Land Use Development Zones

\begin{tabular}{|c|c|c|}
\hline Item & Zone Description & $\begin{array}{l}\text { Important considerations from explanatory notes on permissible } \\
\text { activities as in the Colombo City Development Plan (UDA(1999)) }\end{array}$ \\
\hline 1 & Special Primary Residential Zone (SPRZ) & $\begin{array}{l}\text { This zone is mainly for residential development and having housing } \\
\text { units ranging from a single floor to a maximum of } 3 \text { floors including } \\
\text { the ground floor (Vol.1, pp 49). }\end{array}$ \\
\hline 2 & Primary Residential Zone (PRZ) & $\begin{array}{l}\text { For plot sizes less than } 10 \text { perch in extent, the uses and heights of } \\
\text { buildings permitted are only those permitted in special primary } \\
\text { residential zone. There are } 10 \text { activities for extents more than } 10 \text { perch } \\
\text { (Vol. } 1 \text {, pp 51). }\end{array}$ \\
\hline 3 & Commercial Zone (CZ) & $\begin{array}{l}\text { In this zone environmentally friendly non polluting light industries } \\
\text { such as assembling of electronic components, garment industries are } \\
\text { permitted (Vol. 1, pp 52). }\end{array}$ \\
\hline 4 & Mixed Development Zone (MDZ) & $\begin{array}{l}\text { The mixed development zone is intended to serve as a transitional area } \\
\text { between the primary residential and commercial zones (Vol. 1, pp 51). }\end{array}$ \\
\hline 5 & Concentrated Development Zone (CDZ) & $\begin{array}{l}\text { In this zone, high density development is permitted subject to } \\
\text { individual merits of each site. The guidelines for high rise buildings } \\
\text { are given in Form C of regulation } 35 \text { and other relevant regulation for } \\
\text { high rise development as in planning and building regulation of } 1999 \\
\text { (Vol.II, pp 54). }\end{array}$ \\
\hline 6 & Port Related Activity Zone (PRAZ) & $\begin{array}{l}\text { This activity zone was established specially to accommodate the } \\
\text { activities of the Colombo Port which is to be improved to a very high } \\
\text { standard (Vol. 1, pp 52). }\end{array}$ \\
\hline 7 & Recreational Zone (RZ) & $\begin{array}{l}\text { The following are permitted in this zone: residential, apartments, } \\
\text { commercial offices, banks, restaurants, hotels \& departmental shops } \\
\text { as specified by the development guide plan prepared by UDA (Vol. 1, } \\
\text { pp 53). }\end{array}$ \\
\hline 8 & Environmental Conservation Zone (ECZ) & $\begin{array}{l}\text { In the environmental conservation zone the process of building } \\
\text { development is controlled by the UDA law } 1999 \text {. The activities } \\
\text { prohibited are residential, commercial, industrial and dangerous and } \\
\text { offensive trades (Vol.1, pp 54). }\end{array}$ \\
\hline
\end{tabular}

structured data storage and the case of analysis which reduces the number of activities to eight as shown in the columns seven and eight of Table 1. Eighteen activities of the previous system were found unnecessary with the processing of the applications using the proposed Geographic Information System for land clearance and are denoted as zero time consumption in column 8 (Table 1).

\subsection{Layers and Tables}

The database contains three map layers and three associated attribute data tables. The three map layers are 1) Land Parcel Layer, 2) Buildings layer and the 3) UDA Zoning Layer. The attributes tables are 1) Attribute table of Land Parcels, 2) Attribute table of Buildings and the 3) Attribute table of Zoning Layer. Assigned specific attributes for each layer are given in Table 6, map layers (Figure 5) and attribute Tables (Figure 6) .

The Figures 6a shows the attribute data table for the Land Parcel layer and the Figure 7 shows the Land parcel map layer as an example of the format of GIS database.

\subsection{Benefits}

Management of development information in the prevailing system is done through a manual system of data extraction from field records. The GIS developed by this study enables a system whereby easy management of approvals and other details can be identified and summarized systematically, with minimum time and to 


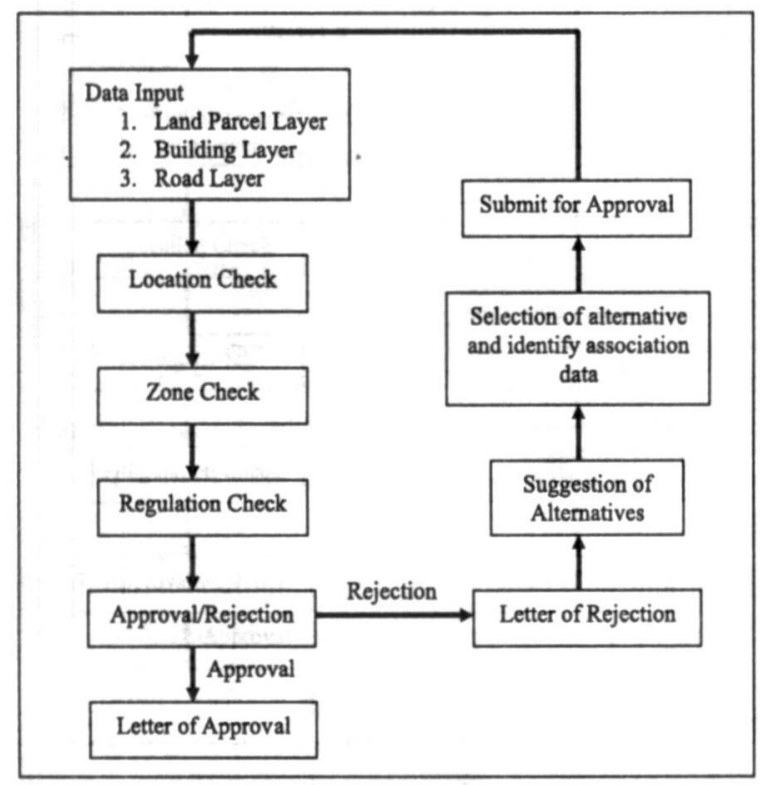

Figure 4 : GIS for the Land Clearance Process

\subsection{Management Information}

Several benefits can be achieved by the introduction of the proposed system to manage land parcel development. The system saves time, improves efficiency, encourages investors by providing alternative site locations, acts quickly while supporting managing decisions, saves costs, easy extracting and easy access to data etc., can be called as such benefits. A significant benefit to the applicant is that the present system enables the receipt of information by the applicant almost immediately. The ability of the system to query and display enables a discussion with the investor in finding alternatives for cases where the applications had been rejected due to deviation with enforced regulations.

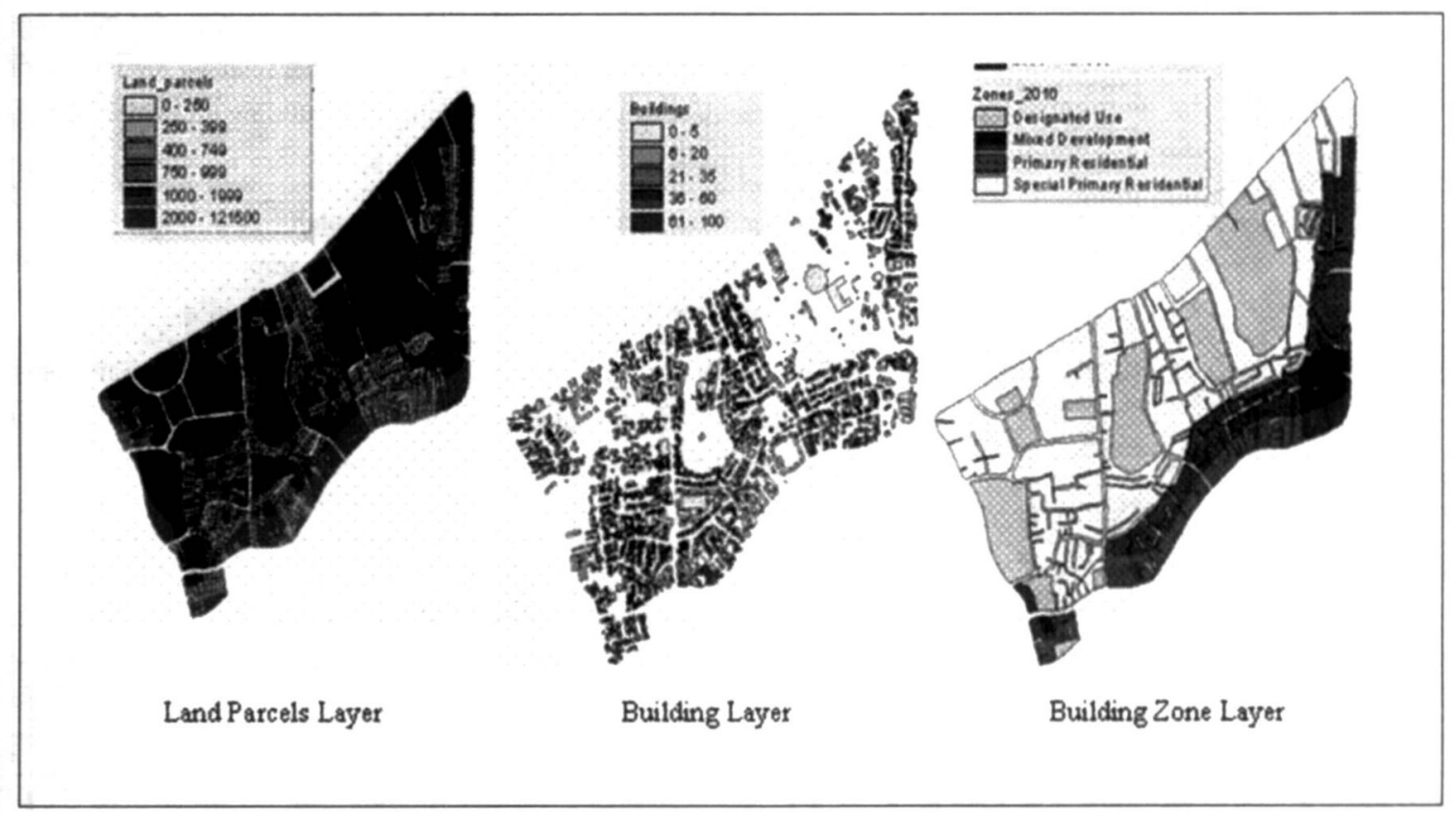

Figure 5 : Map Layers in the Land Information System Database

stipulated accuracies utilizing the processing speed of the computers.

The GIS also enables to identify the status of the land parcels, pending and granted approvals, alternatives available for individuals and also possible combination of land parcels for different types of developments. Therefore the developed GIS can be effectively used for the identification of land types and land availability to suit the particular needs of a developer to contribute efficiently and effectively to the country's economy.

\section{Conclusions}

i. The study enabled the development of a GIS based land information system for accuracy acceptable for land management in urban area, using given information with respect to each land parcel presented in user applications. This system has been developed and verified for the Thimbirigasyaya Ward of the Colombo Municipal Area.

ii. It was identified that the following data and system accuracy checks would enable the development of a good geographic information system for land clearance and management. 
- Accuracy of Data collection from duplicated map copies

- Land Parcel extent accuracy

- Land Parcel length accuracy

- Attribute data accuracy

iii. The Land Information Management System developed with the use of GIS software has significant advantages over the existing system. Clear improvements were visible in the area of labour and time saving and in the provision of alternative solutions. One of the major breakthroughs in the GIS based system is its ability to manage the processed information systematically and also query the availability of alternatives and options within the database that suits the stipulated land regulations.

iv. Development of a similar system for other lands of UDA jurisdiction is necessary to improve the GIS database and establish a GIS based land information system for efficient land development \& management.

\begin{tabular}{|c|c|c|c|c|c|}
\hline Shas & Aot os & $\begin{array}{l}\text { ind_parcets } \\
\text { Bued anese }\end{array}$ & Exinten? & - Dachion & 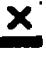 \\
\hline Podeas & 117 & Hovelock Roed & 124.23 & 200 & \\
\hline Poloen & 0 & Vecen Lo & 553.63 & 0.00 & \\
\hline Poten & 10 & Thingoposenod & 461.5 & 11.0 & \\
\hline Potogn & 56 & IT inbionsophod & 4247 & 11.00 & \\
\hline Pofion & 18 & Herelock Roed & 08.34 & 200 & \\
\hline Potem & 17 & Thnbingesenod & 61.07 & 11.00 & \\
\hline Polom & 75 & Hovebet Rad & 780.00 & 200 & \\
\hline Polpon & 67 & Horelock fiod & 152.03 & 200 & \\
\hline Poton & 10 & Hovelock Road & 53.11 & 200 & \\
\hline Poten & 31 & Thinbinaspesenod & 005.26 & 1100 & \\
\hline Pologen & 5 & Ifindionsen Ravd & 47.77 & 11.00 & \\
\hline Pilm & โล & Thins innumesen Rand & KI का & $11 \mathrm{mil}$ & \\
\hline
\end{tabular}

Figure 6a: Attribute Table in the GIS Database for Land Parcels Map Information

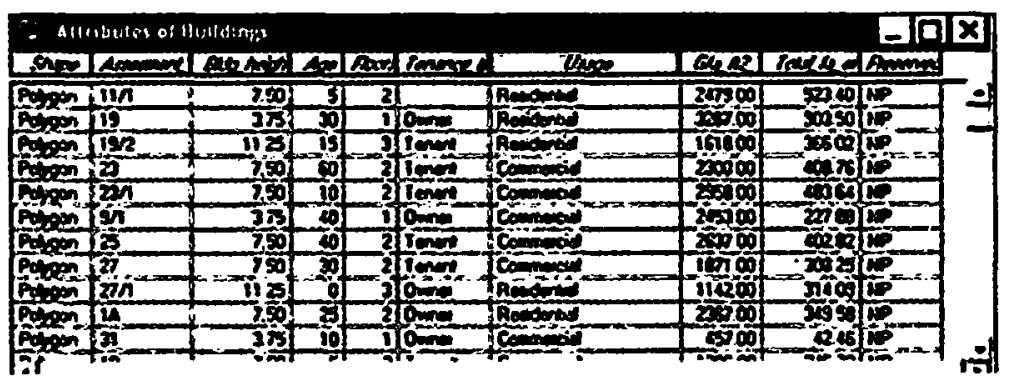

Figure 6b: Attribute Table in the GIS Database for Buildings Map Information

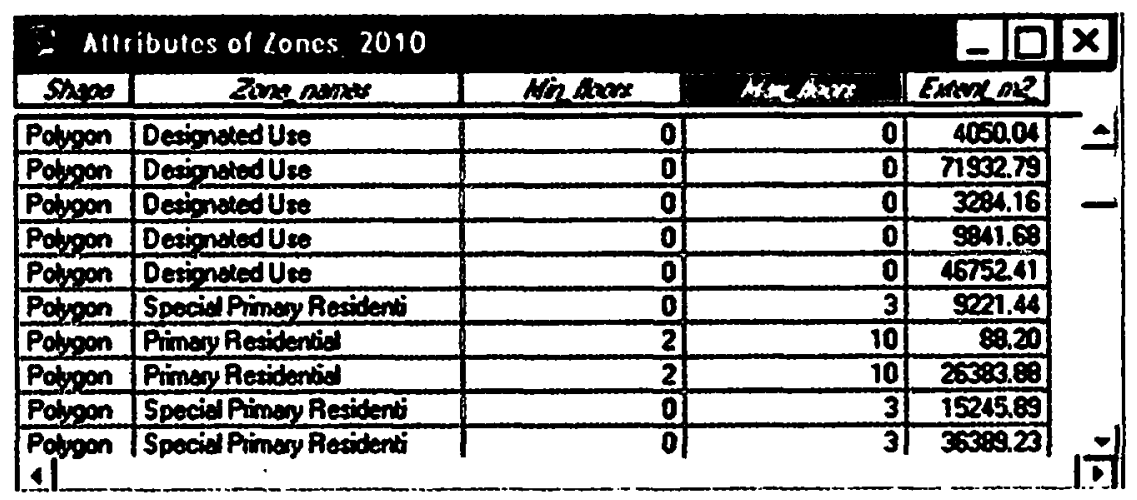

Figure 6c: Attribute Table in the GIS Database for Zoning Map Information

Figure 6: Attribute Table in the Data Layers in Land Information Database 


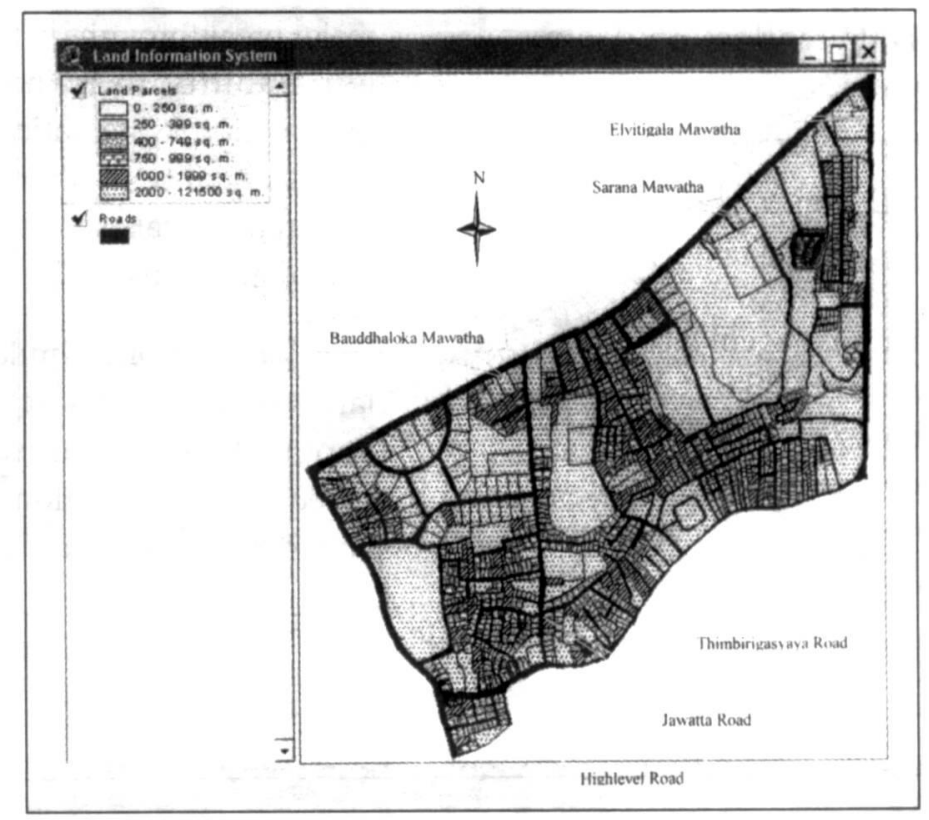

Figure 7 : Land Parcel Layer of the GIS

Table 5 : Comparison of the prevailing and proposed Preliminary Planning Clearance Systems

\begin{tabular}{|c|c|c|c|c|c|c|c|c|c|c|c|}
\hline \multirow{3}{*}{$\begin{array}{l}\text { No. } \\
01\end{array}$} & \multirow[t]{2}{*}{ Location } & \multirow{3}{*}{$\begin{array}{l}* \text { Zone } \\
\text { SPR }\end{array}$} & \multirow{3}{*}{\begin{tabular}{|l} 
Activity \\
Reside \\
ntial
\end{tabular}} & \multicolumn{2}{|c|}{$\begin{array}{l}\text { Minimum Lot } \\
\text { Sizes } \\
\text { Square meters }\end{array}$} & \multicolumn{2}{|c|}{ Maximum Floors } & \multicolumn{2}{|c|}{$\begin{array}{l}\text { Plot Coverage } \\
\text { Percentage }\end{array}$} & \multicolumn{2}{|c|}{ Results } \\
\hline & & & & Permitted & Request & Permitted & Request & Permitted & Request & GIS & Manual \\
\hline & 410/25 Bauddhaloka Mawatha & & & 500 & 545 & 03 & 03 & 65 & 56.4 & $\mathrm{App}^{\mathrm{d}}$ & $\mathrm{App}^{\mathrm{d}}$ \\
\hline 02 & 140 Thimbirigasyaya Road & PR & $\begin{array}{l}\text { Reside } \\
\text { ntial }\end{array}$ & 250 & 662.5 & 10 & 05 & 65 & 64.8 & $\mathrm{App}^{\mathrm{d}}$ & $\mathrm{App}^{\mathrm{d}}$ \\
\hline 03 & 85/12 Jawatta Garden & SPR & $\begin{array}{l}\text { Non } \\
\text { Reside } \\
\text { ntial }\end{array}$ & 500 & 438 & 03 & 03 & 80 & 75 & $\operatorname{Re}^{\mathrm{tdd}}$ & $\operatorname{Re}^{\mathrm{td}}$ \\
\hline 04 & 100 Elvitigala Mawatha & PR & $\begin{array}{l}\text { Reside } \\
\text { ntial }\end{array}$ & 250 & 457.75 & 10 & 05 & 65 & 62.5 & $\mathrm{App}^{\mathrm{d}}$ & $\mathrm{App}^{\mathrm{d}}$ \\
\hline 05 & 71 Havelock Road & MD & $\begin{array}{l}\text { Non } \\
\text { Reside } \\
\text { ntial }\end{array}$ & 150 & 356 & 10 & 04 & 80 & 70.2 & $\mathrm{App}^{\mathrm{d}}$ & $\mathrm{App}^{\mathrm{d}}$ \\
\hline 06 & 10 Gunathilake Garden & PR & \begin{tabular}{|l|} 
Reside \\
ntial
\end{tabular} & 250 & 220 & 10 & 02 & 65 & 65 & $\operatorname{Rej}^{\text {itd }}$ & $\operatorname{Rej}^{\text {it }}$ \\
\hline 07 & 82 Elvitigala Mawatha & PR & \begin{tabular}{|l|}
$\begin{array}{l}\text { Reside } \\
\text { ntial }\end{array}$ \\
\end{tabular} & 250 & 1982.5 & 10 & 09 & 65 & 42.3 & $\mathrm{App}^{d}$ & $\mathrm{App}^{\mathrm{d}}$ \\
\hline 08 & 53/28 Torrington Avenue & SPR & $\begin{array}{l}\text { Reside } \\
\text { ntial }\end{array}$ & 500 & 753.75 & 03 & 03 & 65 & 64 & $\mathrm{App}^{\mathrm{d}}$ & $\mathrm{App}^{\mathrm{d}}$ \\
\hline 09 & 509 Thimbirigasyaya Road & MD & $\begin{array}{l}\text { Reside } \\
\text { ntial }\end{array}$ & 150 & 3285 & 10 & 06 & 65 & 35.1 & $\mathrm{App}^{\mathrm{d}}$ & $\mathrm{App}^{d}$ \\
\hline 10 & 6 Ascot Avenue & PR & $\begin{array}{l}\text { Reside } \\
\text { ntial }\end{array}$ & 250 & 350 & 10 & 04 & 65 & 63.5 & $\mathrm{App}^{d}$ & $\mathrm{App}^{d}$ \\
\hline
\end{tabular}

-* Zone descriptions are as in Table 4. 
Table 6 : Attributes in the GIS for Land Management

\begin{tabular}{|c|l|l|l|}
\hline Layer & \multicolumn{1}{|c|}{ Land Parcels } & \multicolumn{1}{|c|}{ Buildings } & \multicolumn{1}{c|}{ UDA Zoning } \\
\hline 01 & Assessment Number & Assessment Number & Zone Name \\
02 & Road Name & Building Height & Minimum Lot Sizes \\
03 & Land Parcels Extent $\mathrm{m}^{2}$ & Age of Building & Minimum Number of Floors \\
04 & Road Width & Number of Floors & Maximum Number of Floors \\
05 & & Tenancy Type & Zone Extent $\mathrm{m}^{2}$ \\
06 & & Usage & \\
07 & & Ground Floor Area & \\
08 & & Total Floor Area & \\
09 & & Preserved Buildings & \\
\hline
\end{tabular}

v. The developed GIS based land information system can be used not only for land clearance management but also for the preparation of guidelines and make policy recommendations.

\section{References}

1. Chandrasekhar Nori 2003 Land Information System, [online], The Great Arc Festival, London. http://www.gisdevelopment.net/application/ lis/overview/lisrp0001.html Visited on 10th March 2004

2. Government Notifications 1999 Notice of Approval of the Development Plan for the City of Colombo Municipal Council Area - 1999, The Gazette of the Democratic Socialist Republic of Sri Lanka, Extraordinary, Published by Authority.

3. Iftikhar Ahmed and Franklyn Greenaway 2002 GIS Application for Land Planning and Management in Montserrat, West Indies. Grass Users Conference 2002, Trento, Italy.

4. Lee Lik Meng and Tan TS 2002 GIS for PlanMaking in Penang Island: The Roadto Online Planning, School of Housing, Building and Planning (HPB), University Science Malaysia/ Municipal Council of Penang Island.

http://www.onlineplanning.org Visited on 10th March 2004

5. Leelananda 2005 Leelananda H.H., Application of Geographic Information System for Land Clearances in the City of Colombo Sri Lanka, M. Sc. Thesis submitted to University of Moratuwa Sri Lanka, April (Unpublished)
6. Nguyen Dinh Duong, Eddy Nierynck, Tran Van $Y$, and Luc Hens 2000 Land use changes and GISdatabase development for Strategic EnvironmentalAssessment in Ha Long Bay, Quang Ninh Province, Vietnam

7. Peter F. Dale and John D. McLaughlin 1988 Land information Management, Clarendon Press, Oxford, United States.

8. Peter F. Dale and John D. McLaughlim 1988 Land information Management, Clarendon Press, Oxford, United States.

9. Potdar VB 2003 Land Information System in the Present day Context, [online], The Great Arc Festival, London,

http://www.gisdevelopment.net/application/ lis/overview/lisrp0001.html Visited on 10th March 2004

10. United Nations 1995 CITY NET Municipal Land Management in Asia, Regional Network of Local Authorities for Management of Human Settlements, Pp. 65

11. Urban Development Authority. (1999). City of Colombo Development Plan Volume I \& II, Sri Lanka.

12. Weerakoon KGPK \& Dr. Lokupitiya RS 2001 GIS Application for Environmentally

Sustainable Land Use Planning for Colombo Urban Areas, Special Reference to Maharagama Predeshiya Sabha, Research for Industry, Engineering Research Unit, University of Moratuwa, Sri Lanka. 
12. Wijesekera N.T.S., Abeynayake J.C., (2003) Watershed Similarity conditions for Peakflow Transposition - AStudy of River Basins in the Wet Zone of Sri Lanka, Engineer Journal of the Institution of Engineers, Sri Lanka, April

13. Wijesekera N.T.S., Chandrasena K.G., (2002), Key Issues in Erosion Level Estimation for Soil Conservation Planning using Models in Geographic Information Systems, Annual Sessions of the Institution of Engineers, Sri Lanka

\section{Acknowledgements}

The present work was carried out as a part fulfillment requirement for the Master of Science Degree of the first author submitted to the University of Moratuwa. The support given by the Urban Development Authority and the International Center for Geoinformatics Applications \& Training (ICGAT) is gratefully acknowledged. 